\title{
State-Mediated Globalization Processes and the Adoption of Corporate Social Responsibility Reporting in China
}

\section{Christopher Marquis, ${ }^{1}$ Juelin Yin, ${ }^{2}$ and Dongning Yang ${ }^{3}$ \\ ${ }^{1}$ Cornell University, USA, ${ }^{2}$ Xi'an fiaotong-Liverpool University, China, and ${ }^{3}$ Peking University, China}

ABSTRACT Despite the prevalence of global diffusion, little is known about the processes by which international practices are adopted and adapted within organizations around the world. Through our qualitative research on the introduction of corporate social responsibility (CSR) reporting at two leading Chinese companies, we identify a unique set of political mechanisms that we label state-mediated globalization, whereby powerful nation-state actors influence the ways in which corporations adopt and adapt global norms and practices. We find that businesses' needs for political legitimacy from a key stakeholder, in this case the government, leads them to deviate systematically from the global practice in both form and content. These intentional practice adaptations are then legitimized by the government to create internationalization tools and localized standards to aid adoption by other organizations. Our findings illustrate previously unidentified mechanisms by which powerful stakeholders such as the Chinese government may mediate, and thereby direct, the ways in which corporations adopt and adapt global CSR practices. Contributions to understanding the political processes of institutional translation in the context of globalization are discussed.

KEYworDs China, CSR reporting, diffusion, globalization, government, stakeholders, state-mediation

\section{INTRODUGTION}

While the diffusion of global management practices is well studied (Kennedy \& Fiss, 2009; Westphal, Gulati, \& Shortell, 1997), the implementation and adaptation of these practices within organizations is less examined (Gondo \& Amis, 2013). To shed light on this theoretical gap and better understand the mechanisms of how global and domestic institutional pressures influence the globalization of corporate behavior, we investigate one important aspect of China's globalizing political economy: the adoption of global corporate social responsibility (CSR) practices. 
Traditional perspectives on the global spread of CSR focus on the influence of international civil society organizations (Etzion \& Ferraro, 2010; Marquis, Toffel, \& Zhou, 2016), and research has shown a that a growing number of Chinese firms are subject to globalization pressures (Wang, 2009; Zhu, Cordiero, \& Sarkis, 2012). Yet, also salient to these actors are multiple domestic stakeholders such as central and local governments (Hofman, Moon, \& Wu, 2015; Liang, Ren, \& Sun, 2015). However, a theoretical understanding of the role of domestic stakeholders in facilitating and directing the diffusion of global practices is lacking.

The theory we develop addresses this gap by drawing on research on institutional translation processes (Ansari, Reinecke, \& Spaan, 2014; Sahlin \& Wedlin, 2008) and stakeholder management theories (Mitchell, Agle, \& Wood, 1997) to show that different types of stakeholder dependence influence the path of global diffusion. The specific research question we examine is: as practices such as CSR diffuse across national contexts, how do organizations translate and adapt them as a result of their unique stakeholder relationships? To examine these processes, we conducted a qualitative case comparison (Eisenhardt, 1989) of the adoption of CSR reporting at two pioneering Chinese state-owned enterprises (SOEs): China Ocean Shipping (COSCO), China's largest shipping company, and State Grid, China's primary supplier of electricity. These two organizations were among the earliest adopters of CSR reporting in China and so faced similar challenges in adopting the global practice within their own organizations. However, they each also faced different sources of dependence on both international and domestic stakeholders and as a result there were significant differences in the processes by which they translated and implemented CSR reporting within their organization.

We find that their respective deviation from the globalized template is due to a unique political mechanism that we call state-mediated globalization, whereby powerful nation-state actors such as the Chinese government have a specific and important influence on local corporations' adoption of global practices and norms. The theoretical framework we develop articulates how and why deviation from the typically homogenizing forces of globalization can result from firms' co-optation by powerful stakeholders such as the state. Furthermore, the state's interests visà-vis different types of organizations influence the local adoption and adaption of globalized practices. A key finding from contrasting these two case studies is that, in implementing their unique translation strategies, both State Grid and COSCO developed China-specific standards and tools that the Chinese government could then use them to aid in the subsequent diffusion of CSR reporting to other companies. Thus, not only is the global diffusion of CSR mediated by powerful local stakeholders, but also SOEs act as a surrogate for the Chinese state to address both globalization and domestic pressure by reinventing globalized practices. Through this co-evolutionary process, large organizations help the government to address the country's relative lack of intermediary infrastructures such as global skills and knowledge (Khanna \& Palepu, 1997), and they assume some statelike roles by providing public goods that are not being delivered by governments 
(Marquis \& Raynard, 2015). As we elaborate in the Discussion section, this research contributes to understanding the factors underlying the global diffusion of CSR practices (Marquis, Toffel, \& Zhou, 2016), how globalizing practices are changed as they diffuse (Ansari, Reinecke, \& Spaan, 2014), and how emerging economies overcome institutional voids (Khanna \& Palepu, 1997; Marquis \& Raynard, 2015).

\section{THEORETIGAL BAGKGROUND}

Prior research on globalization has shown that corporations' behaviors are significantly shaped by exposure to global norms and practices (Guler, Guillén, \& Macpherson, 2002). Corporations may pick up global models and incorporate them into local practices either directly from the global institutional source or indirectly from prior adopters (Meyer, Boli, Thomas, \& Ramirez, 1997). However, other research has argued that because of idiosyncratic characteristics of institutional environments, such as the historical and political conditions that promote or reject certain global standards and models, national distinctions are maintained even as globalization proceeds (e.g., Dobbin, 1994; Guillén, 1994; Strang \& Meyer, 1993).

While the adoption of global management practices is well studied, the purposeful implementation and adaptation process within organizations remains relatively less examined (Ansari, Reinecke, \& Spaan, 2014; Gondo \& Amis, 2013). Prior research indicates that institutional innovation does not simply 'arrive at an organization's doorstep for adoption' (Campbell, 2004: 78) and that hardly any management practices qualify as 'one-size-fits-all' (Ansari, Reinecke, \& Spaan, 2014). Rather, practices will be actively transferred and translated according to the interests and institutions salient to the adopting firm (Sahlin \& Wedlin, 2008). Adaptation, sometimes also termed 'translation', 'editing', or 'transposition', refers to the process by which an adopter strives to create a fit between an external practice and its particular needs during implementation (Ansari, Fiss, \& Zajac, 2010; Frenkel, 2005; Gondo \& Amis, 2013; Sahlin \& Wedlin, 2008). The adoption of global practices frequently involves combining locally available principles and practices with the new global ones (Campbell, 2004); it may also involve renovating existing organizational structures and inventing new practices. However, most existing studies have examined practice adaptation resulting from incompatibility or misfit between the adopted practice and the adopting organizations, without sufficient attention to the influence of the strategies the organizations and other stakeholders use to shape the ways practices are adapted as they diffuse.

Stakeholder theory has been at the forefront of explaining a firm's adoption of CSR (Liu, Feng, \& Li, 2015; Zhao, 2012; Zheng, Luo, \& Maksimov, 2015). According to Freeman and Reed (1983), stakeholders are individuals or groups who can influence an organization's ability to achieve its goals. While the core tenets of stakeholder theory is that all stakeholders matter and that firms should balance the interests of various stakeholder constituencies, in practice, the balancing 
process has proven to be difficult. In reality, firms can pay attention to only a limited number of stakeholders (Jamali, 2008), and they prioritize the needs and requirements of powerful stakeholders such as the state (Marquis \& Qian, 2014; Yin \& Zhang, 2012).

Our model focuses on how practice adaptation may be a strategic response for organizations to co-opt powerful external stakeholders. An important mechanism of stakeholder influence is dependence (Mitchell, Agle, \& Wood, 1997). As Frooman (1999) argues, stakeholder influence strategy depends on the resource dependency relationships between stakeholders and the firm. Our focus in this paper is therefore to complement the largely internal approach to practice adaptation (e.g., Ansari, Reinecke, \& Spaan, 2014) and to point out the importance of taking the political embeddedness of organizations and the reciprocal influences between the organization and the stakeholders into account as a neglected mechanism in explaining organizational adoption and adaptation of global CSR practices.

\section{THE RISE OF GSR REPORTING IN GHINA}

Corporate CSR practices emerged in China in the late 1990s as multinational companies began requiring their Chinese suppliers to follow global guidelines such as SA8000 and ISO9000 and corporate ethical codes on labor rights and environmental impacts. In the 2000s, international and nongovernmental organizations began to voice concerns about labor and human rights issues in Chinese companies (Gao, 2009; Hofman \& Newman, 2014).

However, as China's transition to a market economy has progressed, the government has also increasingly looked to the country's emerging private and state-owned corporate communities to help bear its social and environmental burdens (Dickson, 2003). In particular, the eleventh Five-Year Plan for National Economic and Social Development (2006-2011) was a milestone. The plan promoted a national vision following the principles of building a 'Harmonious Society' and was widely perceived as a departure from a model of economic growth at all costs to a model in which economic growth was balanced with a need to tackle pressing societal and environmental problems (Hofman \& Newman, 2014; See, 2009). Article 5 of the Company Law that went into effect in 2006 stipulated that a company shall 'abide by laws and administrative regulations, observe social morality and professional ethics, uphold principles of good faith under the supervision of the government and the public, and assume social responsibilities' ${ }^{\left[{ }^{11}\right.}$ In January 2008 the State-owned Assets Supervision and Administration Commission (SASAC) encouraged all 128 large SOEs under their supervision to proactively fulfill CSR requirements to set an example for other types of businesses and advocates that SOEs shall 'integrate CSR into corporate reforms' and 'adopt CSR measures compatible with conditions at the national and organizational level' (Lin, 2010).

As a result of these changes, a few large SOEs such as State Grid, COSCO, China Mobile, and Baosteel Group were the first Chinese companies to publish 
CSR reports. However, without a standard template, one of the key issues for these companies was how to adopt existing international standards and tools of CSR reporting (Raynard, Lounsbury, \& Greenwood, 2013). One of the earliest such CSR frameworks is the United Nations Global Compact (UNGG), a strategic policy initiative launched in 2000 for businesses committed to aligning their operations and strategies with ten universally accepted principles in the areas of human rights, labor, environment, and anticorruption. While the principle-based UNGC provides general CSR guidance for organizations, the Global Reporting Initiative (GRI) is focused on detailed reporting indicators covering economic, environmental, and social activities (Etzion \& Ferraro, 2010). A third international organization, AccountAbility (AA), published the AA1000 Series of Standards. In addition, in 2009, the Chinese Academy of Social Sciences (CASS), a governmentsupported think tank, published the 492-page CSR Report Preparation Guide 1.0 to guide Chinese businesses in publishing CSR reports. Our core research focus is to understand the adoption and implementation of these global CSR reporting practices within the Chinese context.

\section{METHOD}

We follow a comparative qualitative research design, which is suitable for building process theories (Langley, 1999) and illustrating little-known phenomena or new constructs (Eisenhardt \& Graebner, 2007). We chose COSCO and State Grid as our research sites for a number of reasons. First, both are among the earliest adopters of CSR reporting in China, and they have maintained the practice annually since 2005. As pioneers, State Grid and COSCO had to face similar challenges of embedding CSR reporting into an organizational structure without benefit of prior examples by other SOEs. Despite these challenges, both companies have won international and domestic recognition for their CSR reports. Second, as large SOEs headquartered in Beijing, both experience common political pressures from the Chinese government yet are also exposed to varying global competition and domestic pressure. This contrasting dependence on both international and home stakeholders provides an opportunity to observe how different types of stakeholders affects firms' CSR reporting. Third, given SOEs' important role in institutionalizing and legitimating practices, the early adoption patterns of these organizations are important to understanding how globalization affects China and Chinese firms. Thus we believe these firms constitute an ideal context in which to study how global CSR practices were implemented in Chinese organizations.

Table 1 summarizes the basic information of the two companies.

\section{Data Collection}

We relied on four data sources collected between October 2009 and July 2013: a) 27 interviews with top and middle-management and with front-line employees in 
Table 1. Organizational profiles of COSCO and State Grid (2013)

\begin{tabular}{|c|c|c|}
\hline & COSCO & State Grid \\
\hline Founded in & 1961 & 2002 \\
\hline Main Business & $\begin{array}{l}\text { Global shipping, modern logistics, } \\
\text { shipbuilding, and ship repairs }\end{array}$ & $\begin{array}{l}\text { Construction and operation of } \\
\text { power grid }\end{array}$ \\
\hline Ownership & $\begin{array}{l}\text { State-owned, with five publicly listed } \\
\text { subsidiaries }\end{array}$ & State-owned \\
\hline Headquarters & Beijing & Beijing \\
\hline Revenues & US $\$ 7.1$ billion & US $\$ 349$ billion \\
\hline Employees & Over 130,000 & 1.86 million \\
\hline Business Scope & $\begin{array}{l}\text { Ships to over } 160 \text { countries and } \\
\text { regions; subsidiaries or branches } \\
\text { in over } 50 \text { countries }\end{array}$ & $\begin{array}{l}\text { 88\% of China's territory, including } \\
26 \text { provinces, regions and cities; } \\
\text { recently expanded to Philippines } \\
\text { and Brazil }\end{array}$ \\
\hline
\end{tabular}

Table 2. Summary of interviewees

\begin{tabular}{lccr}
\hline \hline & $\begin{array}{c}\text { Senior } \\
\text { management }\end{array}$ & $\begin{array}{c}\text { Middle } \\
\text { management }\end{array}$ & Total \\
\hline COSCO & 3 & 10 & 13 \\
State Grid & 1 & 13 & 14 \\
Standards organizations & 3 & 6 & 9 \\
CSR/Sustainability & 5 & 8 & 13 \\
$\quad$ consultancies & 3 & 6 & 9 \\
Government & 15 & 43 & 58 \\
TOTAL & & & \\
\hline \hline
\end{tabular}

the two companies; b) 31 interviews with external stakeholders involved with or having knowledge of the CSR and reporting activities of the two companies; c) archival data from both companies and reporting standards organizations; and d) secondary data from media reports about both companies' CSR activities.

Interviews. Beginning in 2005, one of the authors had the opportunity to visit both companies several times a year for research and consulting and was thus able to observe both companies from the time they started their reporting practice. This observation included attending scores of internal meetings. It also included many informal conversations with the reporting teams, which informed many of the initial observations about the reporting practices of both companies and identified the key informants for this study. From October 2009 to July 2013, we conducted 58 interviews for the project, summarized in Table 2 by type of organization and level of interviewee.

We conducted 14 interviews at State Grid and 13 interviews at COSCO, most of which were taped and transcribed. Interviews typically lasted 60 to 90 minutes, 
though a few ran as long as three hours. For these informants, we used two sets of interview guidelines: one for company presidents and general managers of major functions that focused on the firms' overall CSR strategy and the decision to adopt CSR reporting practices, and the other for lower-level respondents, including middle managers and front-line employees involved in CSR implementation that focused on the specific CSR reporting practices of the focal firm.

Analysis of the interviews with the managers and staff from the two companies highlighted the role of international and domestic standards and the influence of the Chinese government in their reporting activities. Thus we conducted 22 interviews with representatives from third-party standards organizations and CSR consultancies involved in helping companies implement CSR reporting (see the interview guide in the Appendix). International standards organizations include the UNGC, GRI, and AA. Domestic standards organizations include CASS and China Business Council for Sustainable Development (CBCSD). We also interviewed a number of independent CSR consultancies, including Business for Social Responsibility (BSR), PwC's Sustainability Practice, CSR Asia, Daonong, Det Norske Veritas (DNV), and SynTao. These interviews focused on CSR development of Chinese companies in general and COSCO's and State Grid's CSR activities and reporting in particular.

Because of the state's powerful role in working with various actors to promote CSR reporting, we also conducted nine interviews with government agencies and organizations, including SASAC, the Ministry of Commerce, Development Research Center of State Council, the Shenzhen Stock Exchange, and the Shanghai Stock Exchange. The interviews with government officials focused on the external environment for the development of CSR in China, the government's CSR initiatives, and their evaluation of CSR issues for SOEs in general and of COSCO and State Grid in particular.

Archival documents. In addition to conducting field interviews, we triangulated our data sources by collecting all available internal and public documents directly relevant to both companies' CSR activities between 2004 and 2011. We downloaded and analyzed the content of 12 CSR reports by State Grid and COSCO dating from 2005 to 2010, which provided rich information on the two companies' CSR and business profiles. We also obtained from both companies internal documents and training materials on CSR implementation, including 'State Grid's Guidebook on Implementing Social Responsibility', 'State Grid's White Paper on Green Development', 'State Grid's White Paper on Corporate Values', 'COSCO Sustainable Management System Building Guidance', and 'COSCO Sustainability Reporting Guidance'. Since one of our foci was to examine the adoption and translation of reporting standards in both companies' reporting processes, we also collected and analyzed the CSR guidelines and reporting standards from GRI, UNGC, AccountAbility, SASAC and CASS. 
Secondary data. Secondary data were gathered through media coverage. We searched CNKI database (China Knowledge Resource Integrated Database, an integrative database of Chinese academic and media resources) to retrieve public speeches, articles by some of our key informants, and external media reports and academic articles about the CSR philosophies and activities of both companies. We also performed a separate search of the WTO Tribune, a periodical that examines CSR issues in China, to compare and contrast their coverage of COSCO and State Grid's CSR activities over our research period. The search resulted in 275 articles mentioning State Grid's CSR activities and 110 articles referring to COSCO's CSR activities. We used these secondary data to corroborate our primary data.

\section{Data Analysis}

We started with the strategy of 'stacking comparable cases' (Miles \& Huberman, 1994: 176) by first building individual cases and then comparing across cases to derive a conceptual framework (Eisenhardt, 1989). The first step was to enter all the transcriptions and translate those done in Chinese into English. Next, we triangulated and supplemented the interviews with information from company websites, internal documents, media reports, and both companies' yearly CSR reports. Using these interviews and secondary data, we wrote in-depth descriptive case studies for both companies (see Marquis, Dai, Yang, \& Wu, 2010 and Marquis, Yin, \& Yang, 2011 for published versions of these individual cases). These narrative cases were used to make sense of the development of CSR reporting within both individual companies.

Once the individual cases were completed, we began a cross-case analysis by comparing the cases to identify common dilemmas and extract unique aspects of their reporting process. Our focus on how COSCO and State Grid have overcome the challenge of translating the global reporting practice within their local contexts emerged after observing the dominance of four themes that recurred in different sources of interviews and archival materials and showed important variation in how the two organizations adopted and implemented the reporting practices: specifying stakeholders (why the firm was reporting and whom they were reporting to), theorizing the CSR issues (what to report), engaging with the standards organizations (how to report), and institutionalizing the reporting practice (what happens with the reporting).

To facilitate comparisons around these four themes, we created a contrast figure (Miles \& Huberman, 1994: 195) to diagnose how the global practice of CSR reporting played out across the two cases. Moreover, we content-analyzed six years of CSR reports from the two companies and used two time-ordered matrices (Miles \& Huberman, 1994) to display both the organization's motivation for reporting (Table 3) and the content of that reporting (Table 4) from 2005 to 2010. Although our focus was not on chronological variation, the matrices helped us identify systematic differences between the two organizations. 
Table 3. References to state and global motivations for reporting found in COSCO and State Grid reports

\begin{tabular}{llrrrrrrr}
\hline \hline Motivation for reporting & & 2005 & 2006 & 2007 & 2008 & 2009 & 2010 & Total \\
\hline State references $^{a}$ & COSCO & 2 & 4 & 6 & 9 & 6 & 7 & 34 \\
& State Grid & 7 & 6 & 18 & 11 & 13 & 13 & 68 \\
Global references $^{b}$ & COSCO & 11 & 14 & 26 & 12 & 9 & 8 & 80 \\
& State Grid & 4 & 2 & 6 & 6 & 4 & 8 & 30 \\
\hline \hline
\end{tabular}

Notes: Only coded President's overview letters.

${ }^{a}$ Total references to Central Party, Government, SASAC, State Council, Scientific development, Harmony.

${ }^{b}$ Total references to Globalization, International, UNGC, GRI.

\section{FINDINGS}

In implementing CSR reporting, COSCO and State Grid faced several challenges common to implementing practices in new settings. The initial challenge was to create an institutional imperative for introducing a new practice into the organization. The second obstacle was to translate the ideas into a practice that could be implemented and understood. As pioneers, these organizations had to simplify and distill the properties of CSR reporting - specifying the abstract concept of CSR and elaborating its chains of cause and effect - to make the new practice available for adoption by organizational members.

As noted, our analysis of the data identified four key steps that each company went through in addressing these challenges: (1) identifying and engaging stakeholders, (2) defining the scope of CSR for the organization, (3) engaging with international and domestic standards, and (4) delivering on Chinese government priorities through CSR. Figure 1 summarizes COSCO's and State Grid's different approaches to adapting and reinventing the global practice of CSR reporting; in particular, how they were shaped by the interactions between the organizations and key stakeholders such as the Chinese government, international organizations, and employees. While we present this as a relatively linear sequence, these steps in fact make up a recursive loop that has furthered the institutionalization of CSR in China more generally, as we will discuss in detail below.

\section{Identifying and Engaging Stakeholders}

A key element of the reporting process for both State Grid and COSCO was identifying key stakeholders and then focusing CSR work and reporting on the specific needs and expectations of those key stakeholders. To understand this process, it is necessary to understand how each organization's position vis-à-vis its stakeholders shaped its legitimacy needs and therefore its practices.

While both COSCO and State Grid were subject, as SOEs, to pressure from the Chinese government, COSCO's international connections and influences played 
Table 4. Summary of COSCO and State Grid reports

\begin{tabular}{|c|c|c|c|c|c|c|c|c|c|c|c|c|}
\hline & \multicolumn{2}{|c|}{2005} & \multicolumn{2}{|c|}{2006} & \multicolumn{2}{|r|}{2007} & \multicolumn{2}{|r|}{2008} & \multicolumn{2}{|c|}{2009} & \multicolumn{2}{|c|}{2010} \\
\hline & COSCO & State Grid & COSCO & State Grid & COSCO & State Grid & COSCO & State Grid & COSCO & State Grid & COSCO & State Grid \\
\hline Guidelines & $\begin{array}{l}\text { G2, G3, } \\
\text { UNGC }\end{array}$ & None & G3, UNGC & None & G3, UNGC & G3, AA1000 & $\begin{array}{l}\text { G3, } \\
\text { UNGC }\end{array}$ & $\begin{array}{l}\text { G3, UNGC, } \\
\text { AA1000 }\end{array}$ & $\begin{array}{l}\text { G3, UNGC, } \\
\text { SASAC, } \\
\text { CASS }\end{array}$ & $\begin{array}{l}\text { G3, AA1000, } \\
\text { CASS, } \\
\text { CBCSD } \\
\text { Standard }\end{array}$ & $\begin{array}{l}\text { G3, UNGC, } \\
\text { SASAC, } \\
\text { CASS, ISO } \\
26000\end{array}$ & $\begin{array}{c}\text { SASAC, CASS, } \\
\text { CFIE, ISO } \\
26000, \text { G3 } \\
\text { AA1000 }\end{array}$ \\
\hline GRI index & Yes & No & Yes & No & Yes & Yes & Yes & Yes & Yes & Yes & Yes & Yes \\
\hline UNGC index & Yes & No & Yes & Yes & Yes & Yes & Yes & Yes & Yes & Yes & Yes & Yes \\
\hline $\begin{array}{l}\text { Assurance } \\
\text { provider }\end{array}$ & $\begin{array}{l}\text { DNV } \\
\text { China, } \\
\text { UNGC }\end{array}$ & No & $\begin{array}{l}\text { DNV } \\
\text { China, } \\
\text { UNGC }\end{array}$ & No & $\begin{array}{l}\text { DNV } \\
\text { China, } \\
\text { UNGC }\end{array}$ & DNV China & $\begin{array}{l}\text { DNV } \\
\text { China }\end{array}$ & DNV China & DNV China & DNV China & DNV China & DNV China \\
\hline $\begin{array}{l}\text { Third-party } \\
\text { grading }\end{array}$ & Ungraded & Ungraded & GRI B $^{+}$ & Ungraded & $\mathrm{GRI} \mathrm{A}^{+}$ & Ungraded & $\mathrm{GRI} \mathrm{A}^{+}$ & Ungraded & GRI A $^{+}$ & Ungraded & $\mathrm{GRI} \mathrm{A}^{+}$ & Ungraded \\
\hline Report structure & GRI format & Ad Hoc & GRI format & Ad Hoc & GRI format & Ad Hoc & $\begin{array}{l}\text { GRI } \\
\text { format }\end{array}$ & Ad Hoc & GRI format & Ad Hoc & GRI format & Ad Hoc \\
\hline $\begin{array}{l}\text { Resource input } \\
\text { (working } \\
\text { hours) }\end{array}$ & - & - & - & - & - & - & 1,350 & - & 2,560 & - & 3,744 & - \\
\hline $\begin{array}{l}\text { Report training } \\
\text { (people) }\end{array}$ & 56 & - & 410 & - & 248 & - & 240 & - & 1,095 & - & 1,230 & - \\
\hline Length (pages) & 167 & 58 & 118 & 83 & 136 & 112 & 194 & 114 & 344 & 96 & 324 & 94 \\
\hline
\end{tabular}



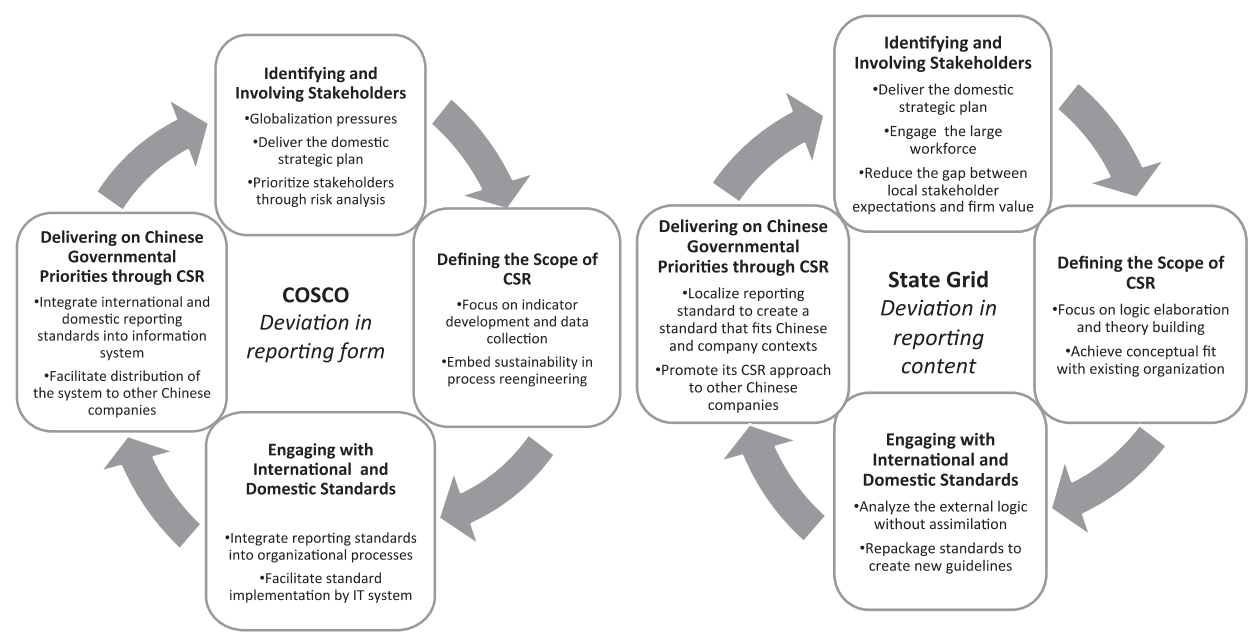

Figure 1. Translation and implementation of CSR reporting at COSCO and State Grid

a much greater role than the Chinese government in its initial motivation to begin CSR reporting. In particular, the decision to join the UNGC was a turning point in COSCO's overall strategy and CSR efforts. When the UN's then-SecretaryGeneral, Kofi Annan, visited China on October 11, 2004, he discussed UNGG principles and the importance of a partnership between the public and private sectors with top Chinese business leaders in Beijing. Viewing participation in the UNGC as 'an opportunity to engage in global business issues and enhance the company's standing within the international shipping community', COSCO's president and CEO, Wei Jiafu, became the only Chinese executive at the meeting to promise not only to adopt but also to fully implement the UNGC principles. COSGO joined the UNGG in January 2005.

The key factor in meeting the legitimacy needs of these international stakeholders was CSR reporting based on international standards developed by organizations such as the UNGG and GRI. In addition, COSCO introduced international standard management tools - including the ISO14000 Environmental Management System, the OHSAS18000 Occupational Safety and Health Management System, and Six Sigma Lean Management - which it believed would help it manage systematic risks and improve stakeholder relationships within the international community.

Moreover, the Chinese government was also a significant stakeholder for COSCO. Responding to the government's mandate to build 'a harmonious, conservation-oriented and law-compliant society', COSCO identified tax payment and employment opportunity as the two main indicators to report to the government. Governmental investors represented by SASAC were also important stakeholders for COSCO.

At State Grid, president and party secretary Liu Zhenya believed that communicating the company's commitment to its community through publishing 
CSR reports could not only help guide its large number of employees in their values and behaviors, but also make State Grid an example as a leading Chinese SOE. State Grid leadership was particularly concerned with promoting dialogue with central and local governments through CSR, in the words of a State Grid informant, to 'bridge the gap between internal values and external stakeholder expectation'. Our interviewees described stakeholder participation, especially with local government stakeholders, as an 'ongoing activity'. Li Weiyang, director of the State Grid CSR Department, remarked: 'Power grid companies are strictly regulated by the government and significant decisions lie externally'. By developing a CSR reporting system, State Grid was able to manage stakeholder participation in a more systematic and structured way.

To more systematically understand the different foci of these two approaches to CSR reporting, we coded the president's overview letters in the six annual CSR reports of both companies. The President's Letter is particularly prominent among the CSR reports' many sections because it is presumed to be the CEO's reflection on the corporation's CSR (Rajandran \& Taib, 2014; Toppinen, Hänninen, \& Lähtinen, 2015). Consistent with our interview findings that reflect how each company positioned its report to meet the needs of key stakeholders, these results show that COSCO oriented its reporting more towards establishing legitimacy with international stakeholders, while State Grid focused more heavily on central and local government concerns, particularly in the initial years.

For example, COSCO's reports frequently used the terms 'international/ internationalization' and 'global/globalization'. UNGC received 47 mentions throughout the COSCO reports over six years. References to Chinese stateoriented motivations for reporting were much less common. State Grid's reports, on the other hand, made frequent references to issues closely aligned with the Chinese government's interests. The terms 'state' and 'government' occurred often, as did references to the key recent governmental philosophies of 'Harmonious Society' and 'Scientific Outlook on Development'. When State Grid published its first CSR report in the spring of 2006, its efforts were recognized by the Chinese government. Premier Wen Jiabao commented, 'They [State Grid] have done well. Companies should be responsible to society and consciously accept supervision by society'. And a number of media reports commended State Grid's report as 'marking a new epoch for CSR development in China'.

Thus, early in the development of their approaches, both organizations identified and involved key stakeholders. COSCO focused on the key standards that were necessary in order to be perceived as legitimate by the international community and secondly on its obligations, as a major SOE, to the Chinese central government. For State Grid, CSR reporting provided a key link to external stakeholders, such as the local governments that set electricity rates throughout China, and secondly to its own large workforce. 


\section{Defining the Scope of CSR}

In 2005, CSR reports were virtually unheard of in China. A key issue for both COSCO and State Grid was how to translate the abstract ideas of CSR into a management philosophy that satisfied their varying stakeholder demands. We found that COSCO focused on developing a systematic indicator database to facilitate reporting according to international standards and, as a result, developed new managerial practices throughout the company to accommodate the indicator system. State Grid, meanwhile, emphasized logic elaboration and theory building to better connect the ideas of CSR with its own organizational systems and to better explain those ideas to its employees and local governments.

As early as 2003, Wei Jiafu assigned COSCO's Research and Development Center to conduct a feasibility analysis for GRI implementation. The preliminary assessment was that GRI requirements were too demanding. GOSCO thereafter began a major corporate project on data collection and process improvements; two years later, it established its sustainable management system, from which it generated the initial 250 reporting indicators presented in its 2005 CSR report.

State Grid, on the other hand, addressed its biggest challenge in translating the foreign practice of CSR reporting into a functional management philosophy: defining CSR properly so that State Grid's managers and particularly its large number of employees at various levels would understand and accept it. 'Changing people's mindset was not an easy job', said Wang Xinwei, the Deputy Director of State Grid's Corporate Communications Department.

According to our State Grid interviewees, although people were doing the same job as before, the meaning of the work - as presented to internal and external constituencies - had changed. In the words of one employee who joined the CSR Department in 2008, 'Though we set up the CSR Department, it doesn't mean State Grid has a new function called CSR'. In our field visit to State Grid's CSR pilot sites, one interviewee from a labor union described CSR as the necklace that connected their daily work: 'We already have a lot of good stuff; now what we need to do is polish them into pearls and then string them with the new concept of CSR'. And one director from a local power company described the greatest change in his job as 'from a follower to a communicator':

We had never heard of social responsibility, but that doesn't mean that we were not undertaking social responsibility. When we now know this new term and look back at what we have accomplished during the eleventh five-year-plan (2006 2010), it seems that most of our achievements were already consistent with CSR, although without the theme of CSR, our activities were mostly spontaneous and random.

Another manager from this same power company illustrated their CSR strategy with an example:

C 2017 The International Association for Chinese Management Research 
Like Chairman Mao used several catchphrases such as 'to serve the people' to lead Chinese people for generations, so we created the terms 'Heart-toHeart' and 'Win-Win Cooperation'. 'Heart-to-Heart' had been a service brand of our company for years, and 'Win-Win Cooperation' was derived out of our previous successful collaboration with local governments. These are the things our employees are familiar with. Using these terms, they easily understand what is the logic behind social responsibility.

COSCO, in accordance with its translation approach, established management committees, including the COSCO Operation and Management Committee and the Sustainable Development and Comprehensive Risk Management Committee, to help implement specific CSR practices, since 'reporting by GRI standards involved a huge number of technical details' (Wei Jiafu, June 19, 2011 ). In contrast, State Grid's CSR Department fell under the Corporate Communications Division, to better align the concept of CSR with corporate values and culture and with public relations.

\section{Engaging with International and Domestic Standards}

A common challenge in the implementation of CSR was that the 'soft' nature of many of the practices made it difficult to quantify and measure progress and to adhere to reporting standards. In addressing and developing the standards to follow, both companies focused on approaches in line with their stakeholder interests. COSCO accordingly engaged in a process of reverse engineering and State Grid was dedicated to forward engineering. That is, COSCO's strategy was to start by researching international standards closely and to integrate them into organizational strategy and routine, believing that building a management system was essential for high-quality reporting. Wei Jiafu explained why it took COSCO two years to prepare for its first report: 'GRI has such strict requirements about report content, structure, and indicators that [an organization's ability] to compile sustainable development reports up to GRI standards becomes a hallmark of the quality of the organization's sustainable development management system'. Instead of mostly adopting existing cases and data, COSCO paid much attention to building an internal system compatible with the GRI and UNGC, which Ma Xinying, the director of COSCO Sustainable Development Office, attributed to President Wei's foresight,

We used to do annual summaries of work, but the work was not quantifiable and comparable among divisions. President Wei had the insight that the GRI system was a great management tool not only for reporting but also for internal review.

Wei thus asked the System Management Office to identify key performance indicators and benchmark against General Electric (GE) to learn 6-Sigma techniques. After two years of process reengineering, COSCO established its 
sustainable management system, from which it generated the initial 250 reporting indicators presented in the first CSR report in 2005. This dedication to systembuilding has not only helped COSCO win the UNGC's Communication on Progress (COP) Award since its first report, but also laid the foundation for COSCO's reporting in the latter years. Every November, COSCO begins collecting data for the reporting indicator system for the following year. After assembling the data and evaluating how they corresponded to the GRI framework COSCO invited external evaluation by experts from the UNGC China Network, GRI, CASS, and SASAC. After that, COSCO embedded the updated framework into the following year's report structure, which subsidiaries then used to begin collecting data for reporting. To ensure external reliability, COSCO would submit the report to external auditing firms such as DNV for independent assurance, and then finally to GRI and UNGG for grading.

State Grid adopted a very different approach to engaging with standards in its reporting process. Unlike COSCO, instead of faithfully complying with and integrating various international templates into a new management structure, State Grid repackaged the standards to create its own reporting guidelines. In September 2006, when State Grid joined the UNGC, top management had to make a strategic decision whether to adopt international standards for reporting or to develop propriety standards. After studying the major international standards and the logic behind each, top management and the report teams concluded that it was more reasonable for State Grid to develop its own standards to better fit its own needs. As the leader of the report team explained:

To follow the international standard would make our job easier. It is like doing financial statements and you just need to put the data in the right place, but it will not fit our company's needs.... These international practices were of little help for us because they didn't work from an implementation perspective, which our leaders found difficult to accept. So we decided to develop our own standards based on our logic and the problems we need to solve.

Consistent with the interview findings, our coding of the CSR reports of the two companies revealed systematic differences both in the report structure and in contents. As the comparison in Table 4 shows, while COSCO has followed the GRI reporting framework since its first report in 2005, State Grid's report structure has been adapted each year according to the company's identification of the year's major themes of reporting and its improved CSR approach and model. Moreover, while COSCO focused on disclosing resources and training hours devoted to reporting, and on benchmarking quantifiable indicators against the GRI framework, analogous details from State Grid reports are not reported. Although State Grid mentioned the GRI G3 Guidelines and AA1000 Series on the first page of its reports and, starting in 2007, included 'UNGC index' and 'GRI Index' in the final section of its reports, it admitted that these standards did not significantly affect the company's organization of its activities and reporting. 
'We cannot waste money and manpower simply for the sake of introducing international indicators, especially when some indicators are not necessary from our management perspective but consume tremendous input', a State Grid informant explained.

\section{Delivering on Governmental Priorities and Facilitating Diffusion of GSR}

COSCO and State Grid comprise a theoretically useful comparison because of their varying business foci and differences across their relevant stakeholders. A final key element of their CSR reporting work is that while each company's approach was shaped by the idiosyncrasies of its position with respect to global and local stakeholders, both had tight relations with the Chinese state, which, in turn, facilitated the spread of their unique reporting templates to other Chinese companies, helping the Chinese government overcome a significant 'institutional void' in China (Marquis \& Raynard, 2015).

In 2008, COSCO launched a Sustainable Development Information System, a unique reporting form that enabled it to access its domestic and overseas subsidiaries' CSR indicators through the Internet and to manage the reporting process more efficiently. The platform was designed by the Sustainable Development Office, following the requirements of international standards and initiatives - including GRI, UNGC, AA1000, and OECD - and domestic guidelines such as the SASAC Guideline and CASS's CSR Report Preparation Guide. The IT staff involved in developing the system emphasized the compatibility and extendibility of the information system as the greatest advantage, 'It is like building a high-rise, and what we are doing is laying a good foundation so that we will be able to satisfy the requirements of different CSR standards as well as government agencies'. Over the years, COSCO has accommodated the expanding requirements of different standards; its database now includes 74 parent indicators and 726 sub-indicators.

Apart from using this system for its own internal reporting, COSCO has promoted it among other state-owned enterprises, which, as our interviewees noted, is what SASAC expected it to do. 'We are not developing the information system with closed doors', explained one respondent from the IT subsidiary, 'You may know that SASAC manages all central SOEs and one department under SASAC is responsible for the promoting of CSR. They often organize work meetings where we presented our case to other SOEs'. A few leading Chinese SOEs, including China Minmetals, approached COSCO for possible cooperation. In 2009, the China National Offshore Oil Corporation (GNOOG) licensed COSCO's CSR information system, paying a one-time service fee of US\$92,308. COSCO customized around one-third of its information system for GNOOC, based on the latter's industry and management structure, and guided CNOOC throughout the processes of writing the project proposal, CSR 
reporting, and system use training. 'So far we just want to cover the implementation costs, because we want to show that we are just promoting CSR through the SASAC platform instead of making money out of CSR', the general manager of COSCO's IT subsidiary explained. Thus, with the encouragement and support of the government, COSCO has worked to spread the CSR management system it developed to other companies, particularly other to SOEs.

Taking an alternative path, State Grid focused much more on developing a unique theory of CSR implementation for Chinese companies, and it partnered with CASS in diffusing a new set of China-specific standards. In December 2007, State Grid published its own reporting standard, a 90-page 'Guidance for the Implementation of CSR', the first CSR guidance developed by a Chinese company. In it, State Grid proposed a Total Responsibility Model as the key framework for reporting. Moreover, in the company's 2009 and 2010 reports, it specifically referred to SASAC's 'Guidance for Large SOEs on their Social Responsibility Obligations', CASS's 'CSR Report Preparation Guide', and ISO26000 standards, as well as the G3 Guidelines and AA 1000. Li Weiyang described State Grid's reporting process as 'independent innovation' and 'forward engineering':

Our standard is State Grid's CSR theory, State Grid's Guidance for the Implementation of CSR. This Guidance and this model are our essential standards. So what are the other standards to us? ... We don't compile our reports according to these [international] standards, they are only for reference.

State Grid's systematic efforts at theorizing CSR to fit the Chinese company context have also been held up by SASAG and the Ministry of Commerce as a prototype for CSR reporting. The company's reports were selected as the model at various domestic CSR awards and government seminars. Moreover, State Grid was chosen by CASS as the only company to join in the co-development of China specific CSR standards and contributed its CSR reporting model to China's ISO26000 standard formulation. As one of the government officials commented, 'The unique feature of the Chinese delegation for ISO26000 standard formulation is that Chinese companies such as State Grid for the first time have gained a voice in international social responsibility standard-making'. In all these ways, State Grid's experience in creating a unique Chinese approach to CSR reporting is being transmitted by the government to other Chinese companies.

\section{NATION-STATE MEDIATION AS A PATHWAY OF GLOBAL GSR DIFFUSION}

In summary, as each organization translated the concepts of CSR and CSR reporting to meet its own needs, they adopted and intentionally adapted the global reporting practice to develop idiosyncratic theories, tools and standards not only as a result of the companies' governmental connections but as prior literature has suggested also other key stakeholders such as international customers and 


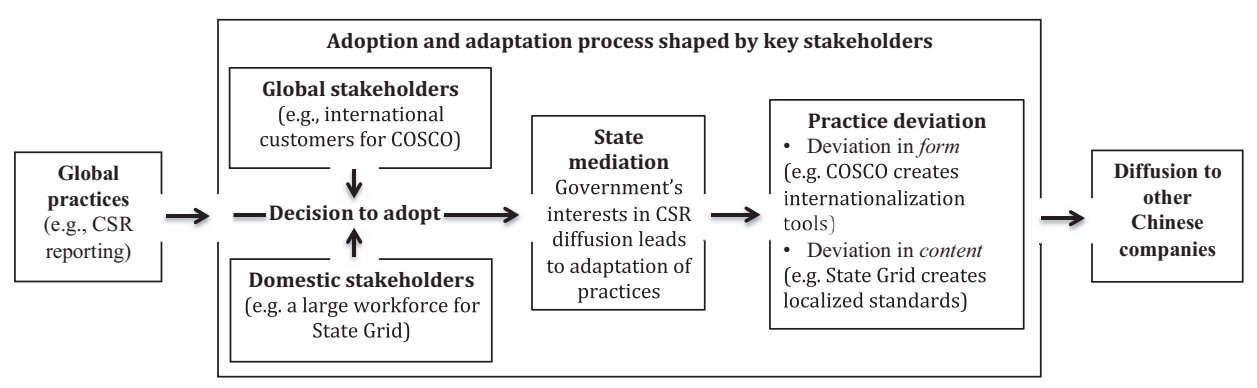

Figure 2. State-mediated globalization processes and the adoption of CSR reporting in China

organizations in the COSCO case (Etzion \& Ferraro, 2010), and a large workforce in the State Grid case (Zhu, Yin, Liu, \& Lai, 2014). While this intentional variation from the global reporting practice helped State Grid and COSCO refine their own processes, their work was also intended to aid other Chinese companies in their implementation, following the advocacy of SASAC. Thus, as we describe below, a novel contribution one may draw from contrasting these cases is an illustration of how the state can mediate the globalization of practices. In Figure 2 we develop a theoretical model of this recursive nation-state-mediated global diffusion process, incorporating both the translation pathways discussed above and also more specifically, how the practice adaptation process was mediated by the actors' dependence on this powerful stakeholder.

As described above, a crucial element of the decision to adopt was each company's dependence on key stakeholders (see the left part of the middle box in Figure 2). Because of its position as a global shipping business, COSCO's president sensed that CSR reporting offered an opportunity to carry out the company's new strategic plan and to differentiate itself among global shipping companies (global customer dependency) as well as among central SOEs (government dependency). State Grid's president, on the other hand, became interested in CSR reporting as a solution to the problem of the 'gap between internal and external stakeholders', seeing government as the key stakeholder to manage, not only because the company relies so heavily on the state for resources (government dependency) but also because it regards CSR as a cultural toolkit to engage its numerous employees. Stakeholders with such different interests subjected the two companies to different legitimacy pressures, which also led in turn to substantially different pathways of translating and implementing the abstract idea of CSR. In both companies' cases, the translation process was shaped by the Chinese government,

As these organizations adapted the global standards, key deviations were made with regard to the form and content of what was adopted. For instance, COSCO's sustainable development information system was an instance of translated institutional work focused on intentional deviation of form. Having adopted international standards that did not initially fit its organization, COSCO responded by designing systems to collect and report on key international CSR 
metrics from its various branches located not just in China but also overseas, so as to accommodate the requirements of international standards organizations and initiatives such as the GRI and UNGG. These internationalization tools, which could be used by other Chinese organizations to help implement CSR reporting, have thus facilitated theorization and institutionalization of CSR in China, as well as the export of standardized systems to other SOEs and UNGC members.

A key finding regarding State Grid's strategy is that the company worked closely with the government to develop and legitimize its standard by emphasizing unique CSR content that was specific to the Chinese context. To develop the CSR content that met the needs of its key stakeholders (e.g. tight government connections, a large number of employees having no knowledge of CSR), following its first report, State Grid paid great attention to the definition of CSR, its values, and its causal logic as they applied to China's unique situation. Although State Grid recognized the legitimacy-enhancing effect of international standards, it developed a customized CSR Guidebook to take advantage of the attention paid to CSR reporting so as to better communicate its own strategy externally and internally - as a culturebuilding exercise - while deemphasizing the importance and fit of the international standards. In addition, conceptual tools that focused on explaining what CSR is for Chinese companies, and in particular SOEs, were created to aid in the diffusion of this set of localized standards with the help of government authorities and agencies such as SASAC and CASS. In this way, State Grid represents how the content of the 'new' global CSR was repackaged and theorized in a way that fit with the 'old' organizational system, allowing for easier diffusion in the Chinese context, particularly under the advocacy of Chinese government.

A crucial mechanism that induced and facilitated both companies' intentional deviation in both form and content is the recursive political process, which we label state-mediation (see the middle part of the middle box in Figure 2). Under the direction and guidance of the government, both organizations were engaged in significant practice adaptation, either by reinventing internationalization tools (form deviation) beyond the requirements of global standards or by developing local interpretations and understandings of global standards (content deviation) (see the right part of the middle box in Figure 2). We thus see the state as a mediator of the organizational adoption and adaptation of globalized practices. This mechanism reflects a co-evolutionary process, since the adoption and adaptation are not merely an outcome of environmental selection or managerial adaptation, but a joint outcome of stakeholder dependency, power, and intentional strategic adaptation.

In this way, the government not only aided the development of the new CSR approaches and models at both companies, but also enabled both companies to create tools and standards that could then help other Chinese companies implement CSR reporting and also facilitate the institutionalization of Chinese government's new initiatives (see the right-most box in Figure 2). Thus, by this coevolutionary process, large corporations in China can also help the government address an 'institutional void' that exists with regard to CSR implementation by 
providing a toolkit that feeds back to the governmental policies such as sustainable development, harmonious society, and scientific development (Marquis \& Qian, 2014), aiding Chinese companies in gaining international competitive advantages as well as local legitimacy (Carney, Gedajlovic, \& Yang, 2009).

\section{DISGUSSION}

Our study suggests that when globalization pressures and nation-state interests intersect, organizations match their legitimation strategies to the most pronounced sources of legitimacy pressure and to organizational factors such as dependency on key stakeholders. Our study underscores the enabling condition of stakeholder, particularly governmental, dependence for the strategic adoption and adaptation of global practices. In an emerging economy like China's, a variety of institutional forces may penetrate into the social field of an organization, exerting different or contradicting demands on organizational actions (Marquis \& Raynard, 2015).

Our findings reveal external stakeholder dependence as a mechanism that shapes the adaptation of global CSR practice in a local context. While prior studies have argued that stakeholders such as the government often find ways to influence firm behavior, relatively little attention is paid to the strategies firms might undertake to respond to stakeholder influences (Zhao, 2012). Our findings differ from other well-noted symbolic strategies, such as decoupling (Meyer \& Rowan, 1977), where organizations create and maintain a gap between external presentation and internal practice to gain external legitimacy while maintaining internal flexibility. In contrast, we identify the intentional deviation from the adopted global practice as a way that organizations symbolically comply with international pressures by deemphasizing one set of standards and making explicit an alternative that fits the expectations of their key stakeholders. SOEs depend on the central government and SASAC for crucial resources such as capital, information, reputation and protection. Further, SOEs may enjoy discretion in adopting global practices since they do not face identical expectations from international and local stakeholders. In such contexts, maintaining legitimacy with key stakeholders might involve intentional deviation other than isomorphism with the global standards (Oliver, 1991). In showing that the externally legitimate practice was re-theorized to better serve the interests of key stakeholders, we join other recent efforts to develop new mechanisms by which corporations uniquely adopt global practices in an emerging economy where state influence is more salient (Marquis, Toffel, \& Zhou, 2016; Okhmatovskiy \& David, 2012).

Second, we provide valuable empirical evidence showing how the nation-state aids the development of local tools and standards to create alternative pathways for the adoption of global CSR practices by local firms, and that these processes are reformulated in a way that uses corporations to meet governmental needs. While an emerging literature indicates the role of the state in bridging firm-level CSR and national-level development needs (e.g. Subramaniam, Kansal, \& Babu, 
2015; Zhao, 2012), we find that the government plays a key role in mediating the globalization process, working with local businesses to create locally legitimate standards and with the global players to create tools for wider diffusion of global standards in China (Gugler \& Shi, 2009). The existence of institutional voids in the emerging economy context of China has provided the space and opportunity for such practice deviation. Intentional deviation of practice is one of the mechanisms that allow for firms and the state to successfully address constraints of institutional voids and capitalize on the opportunities they create. As a result, the spread of CSR reporting in China is not a homogenizing tool that weakens cross-national variation, but rather, through this political process, an instrument for the Chinese state seeking increased legitimacy from (a) the global community that questions internationalizing Chinese corporations as unsustainable (Child \& Rodrigues, 2005; Gugler \& Shi, 2009) and (b) domestic private businesses that see the state's support of state-owned enterprises as crippling the country's markets and social systems (Wang, 2009).

Although our theoretical model of a state-mediated CSR diffusion process has been derived in the Chinese context where state influence is stronger than many other countries, these crucial political dimensions may have broader implications elsewhere. In Europe, for instance, a number of governments have used the rhetoric of CSR to legitimate new regulations. The UK government has used disclosure as a tool in implementing legislation, which not only encourages, but in practical terms, requires major companies to adopt CSR policies (McBarnet, 2007). In Africa, while international CSR standards such as the UNGG have been increasingly adopted, governments and leading organizations have worked together to develop their own CSR principles and standards, such as the Monrovia Principles, adapted to and coevolving with international standards (Forstater, Zadek, Guang, Yu, Hong, \& George, 2010). As a result of the significant role of SOEs and state interests in many parts of the world (e.g. Bruton, Peng, Ahlstrom, Stan, \& Xu, 2015), these insights into the key political link between governmental influence and the leadership of companies such as SOEs suggest future studies of global diffusion should more fully take into account the relevance of domestic institutions and the role of nation-state governments in mediating the adoption of global norms and standards. While China is clearly an interesting strategic research site for SOE research, more research is needed to test whether research findings on the CSR strategies of SOEs in China have relevance to SOEs elsewhere.

In sum, our study has shown that while globalization is a powerful isomorphic force in the world, it operates within the constraints and channels created by both international and national institutions. Our empirical case shows that diffusion of globalized practices is not a mechanical transfer of principles and practices originating elsewhere; rather, such diffusion results from political processes between local actors and mediating institutions, involving economic and political interests. SOEs are faced with mixed institutional logics of state ownership and private ownership, financial and nonfinancial goals, globalization pressure, and local 
state interests. Changes in China's political-economic regime positioned Chinese SOEs to take leading positions in the state economy and encouraged them to import global rationalized practices at the same time. Their collaboration with state officials and international organizations enabled the process of adoption to combine organizational infrastructures and local contexts, providing solutions that not only work for the organization itself, but also make up for gaps in the countries' political, social, and economic infrastructures. A unique aspect of our approach is a close-up view of the interaction between institutional conditions in the global sphere and local actors such as corporations, and we encourage future research on the micro-dynamics of diffusion and translation at the intersection of local and global processes.

\section{NOTES}

We appreciate the help and guidance of Management and Organization Review Senior Editor Till Talaulicar and the anonymous reviewers and also thank John Almandoz, Yunzhou Du, Peter Hofman, Yuhuan Liu, Mia Raynard, Andras Tilscik, Danqing Wang, Dean Xu, Jun Yang, and audience members at the 2012 International Association for Chinese Management Research (IACMR) Conference, Nottingham University China Business School, and Zhejiang University for their comments on previous versions of the paper. The second author also thanks the support provided by National Natural Science Foundation of China (Grant Nos. 71672146, 71202025), Jiangsu Philosophy \& Social Science Funding Programme of Jiangsu Department of Education (Project No. 2015SJD618), and the Research Development Fund of Xi'an Jiaotong-Liverpool University.

[1] http://www.acga-asia.org/public/files/China_Company_Law_Amended_Oct2005.pdf

\section{REFERENGES}

Ansari, S. M., Fiss, P. C., \& Zajac, E. J. 2010. Made to fit: How practices vary as they diffuse. Academy of Management Revieze, 35(1): 67-92.

Ansari, S. S., Reinecke, J., \& Spaan, A. 2014. How are practices made to vary? Managing practice adaptation in a multinational corporation. Organization Studies, 35(9): 13131341.

Bruton, G., Peng, M. W., Ahlstrom, D., Stan, C., \& Xu, K. 2015. State-owned enterprises around the world as hybrid organizations. Academy of Management Perspectives, 29(1): 92114.

Campbell, J. L. 2004. Institutional change and globalization: Exploring problems in the new institutional analysis. Princeton, NJ: Princeton University Press.

Carney, M., Gedajlovic, E., \& Yang, X. 2009. Varieties of Asian capitalism: Toward an institutional theory of Asian enterprise. Asia Pacific Journal of Management, 26(3): 361-380.

Child, J., \& Rodrigues, S. B. 2005. The internationalization of Chinese firms: A case for theoretical extension? Management \& Organization Revieze, 1(3): 381-410.

COSCO. 2005-2010. COSCO sustainability report. [Cited July 2013]. Available from URL: http: //www.cosco.com/GC_report/

Dickson, B. J. 2003. Red capitalists in China: The party, private entrepreneurs, and prospects for political change. Cambridge, UK: Cambridge University Press.

Dobbin, F. 1994. Forging industrial policy: The United States, Britain, and France in the Railway Age. New York: Cambridge University Press.

Eisenhardt, K. M. 1989. Agency theory: An assessment and review. The Academy of Management Revieze, 14(1): 57-74.

Eisenhardt, K. M., \& Graebner, M. E. 2007. Theory building from cases: Opportunities and challenges. Academy of Management Journal, 50(1): 25-32. 
Etzion, D., \& Ferraro, F. 2010. The role of analogy in the institutionalization of sustainability reporting. Organization Science, 21(5): 1092-1 107.

Forstater, M., Zadek, S., Guang, Y., Yu, K., Hong, C. X., \& George, M. 2010. Corporate responsibility in African development: Insights from an emerging dialogue. Working paper of the Corporate Social Responsibility Initiative. Cambridge, MA: Harvard University.

Freeman, R. E., \& Reed, D. L. 1983. Stockholders and stakeholders: A new perspective on corporate governance. California Management Revieze, 25(3): 88-106.

Frenkel, M. 2005. The politics of translation: How state-level political relations affect the crossnational travel of management ideas. Organization, 12(2): 275-301.

Frooman, J. 1999. Stakeholder influence strategies. Academy of Management Revieze, 24(2): 191-205.

Gao, Y. 2009. Corporate social performance in China: Evidence from large companies. Journal of Business Ethics, 89(1): 23-35.

Gondo, M. B., \& Amis, J. 2013. Variations in practice adoption: The roles of conscious reflection and discourse. Academy of Management Revieze, 38(2): 229-247.

Guillén, M. F. 1994. Models of management: Work, authority, and organization in a comparative perspective. Chicago: University of Chicago Press.

Guler, I., Guillén, M. F., \& Macpherson, J. M. 2002. Global competition, institutions, and the diffusion of organizational practices: The international spread of ISO 9000 quality certificates. Administrative Science Quarterly, 47(2): 207-232.

Gugler, P., \& Shi, J. Y. J. 2009. Corporate social responsibility for developing country multinational corporations: Lost war in pertaining global competitiveness? Journal of Business Ethics, 87(S1): 3-24.

Hofman, P. S., \& Newman, A. 2014. The impact of perceived corporate social responsibility on organizational commitment and the moderating role of collectivism and masculinity: Evidence from China. The International Journal of Human Resource Management, 25(5): 631652.

Hofman, P. S., Moon, J., \& Wu, B. 2015. Corporate social responsibility under authoritarian capitalism dynamics and prospects of state-led and society-driven CSR. Business \& Society, doi:10.1177/0007650315623014.

Jamali, D. 2008. A stakeholder approach to corporate social responsibility: A fresh perspective into theory and practice.Journal of Business Ethics, 82(1): 213-231.

Kennedy, M. T., \& Fiss, P. C. 2009. Institutionalization, framing, and diffusion: The logic of TQM adoption and implementation decisions among US hospitals. Academy of Management Journal, 52(5): 897-918.

Khanna, T., \& Palepu, K. 1997. Why focused strategies may be wrong for emerging markets. Harvard Business Revieze, 75(4): 41-48.

Langley, A. 1999. Strategies for theorizing from process data. The Academy of Management Revieze, 24(4): 691-710.

Liang, H., Ren, B., \& Sun, S. L. 2015. An anatomy of state control in the globalization of state-owned enterprises. Journal of International Business Studies, 46(2): 223-240.

Lin, L.-W. 2010. Corporate social responsibility in China: Window dressing or structural change? Berkeley Journal of International Laze, 28(1): 64-100.

Liu, Y., Feng, T., \& Li, S. 2015. Stakeholder influences and organization responses: A case study of corporate social responsibility suspension. Management and Organization Revieze, 11(3): 469-491.

Marquis, C., Dai, N., Yang, D., \& Wu, H. 2010. State Grid: Corporate social responsibility. Harvard Business School Case, 410141.

Marquis, C., \& Qian, C. 2014. Corporate social responsibility reporting in China: Symbol or substance? Organization Science, 25(1): 127-148.

Marquis, C., \& Raynard, M. 2015. Institutional strategies in emerging markets. The Academy of Management Annals, 9(1): 291-335.

Marquis, C., Toffel, M., \& Zhou, Y. 2016. Scrutiny, norms, and selective disclosure: A global study of greenwashing. Organization Science, 27(2): 483-504.

Marquis, C., Yin, J., \& Yang, D. 2011. COSCO: Implementing sustainability. Harvard Business School Case, 412081.

McBarnet, D. J. 2007. Corporate social responsibility beyond law, through law, for law: The new corporate accountability. In D. J. McBarnet, A. Voiculescu, \& T. Campbell (Eds.), The 
new corporate accountability: Corporate social responsibility and the laze: 9-56. Cambridge: Cambridge University Press.

Meyer, J. W., \& Rowan, B. 1977. Institutionalized organizations: Formal structure as myth and ceremony. American Journal of Sociology, 83(2): 41-62.

Meyer, J. W., Boli, J., Thomas, G. M., \& Ramirez, F. O. 1997. World society and the nation-state. The American Journal of Sociology, 103(1): 144-181.

Miles, M. B., \& Huberman, A. M. 1994. Qualitative data analysis: An expanded sourcebook (2nd ed.). Thousand Oaks, CA: Sage Publications.

Mitchell, R. K., Agle, B. R., \& Wood, D. J. 1997. Toward a theory of stakeholder identification and salience: Defining the principle of who and what really counts. Academy of Management Review, 22(4): 853-886.

Okhmatovskiy, I., \& David, R.J. 2012. Setting your own standards: Internal corporate governance codes as a response to institutional pressure. Organization Science, 23(1): 155-176.

Oliver, G. 1991. Strategic responses to institutional processes. Academy of Management Revieze, 16(1): 145-179.

Rajandran, K., \& Taib, F. 2014. The representation of CSR in Malaysian CEO statements: A critical discourse analysis. Corporate Communications: An International Journal, 19(3): 303317.

Raynard, M., Lounsbury, M., \& Greenwood, R. 2013. Legacies of logics: Sources of community variation in CSR implementation in China. In M. Lounsbury \& E. Boxenbaum (Eds.), Research in the sociology of organizations: Institutional logics in action, 39: 243276. Bingley, UK: Emerald Group.

Sahlin, K., \& Wedlin, L. 2008. Circulating ideas: Imitation, translation and editing. In R. Greenwood, C. Oliver, K. Sahlin, \& R. Suddaby (Eds.), The Sage handbook of organizational institutionalism: 218-242. Los Angeles: Sage.

SASAC. 2008. Guidelines to the state-owned enterprises directly under the central government on fulfilling corporate social responsibilities. [Cited April 2012]. Available from URL: http://www. sasac.gov.cn/n85881/n85901/c991161/content.html

See, G. 2009. Harmonious society and Chinese CSR: Is there really a link? Journal of Business Ethics, 89(1): 1-22.

State Grid Corporation of China (SGCG). 2005-2010. Corporate social responsibility report. [Cited July 2013]. Available from URL: http://www.sgcc.com.cn/ywlm/socialresponsiility/ index.shtml

Strang, D., \& Meyer, J. 1993. Institutional conditions for diffusion. Theory and Society, 22(4): $487-511$.

Subramaniam, N., Kansal, M., \& Babu, S. 2015. Governance of mandated corporate social responsibility: Evidence from Indian government-owned firms. Journal of Business Ethics, doi:10.1007/s10551-015-2804-0

SynTao. 2012. A journey to discover values: A study on sustainability reporting in China. [Cited June 2013]. Available from URL: http://www.syntao.com

Toppinen, A., Hänninen, V., \& Lähtinen, K. 2015. ISO 26000 in the assessment of CSR communication quality: CEO letters and social media in the global pulp and paper industry. Social Responsibility Journal, 11(4): 702-715.

Wang, J. 2009. Global-market building as state building: China's entry into the WTO and market reforms of China's tobacco industry. Theory and Society, 38(2): 165-194.

Westphal, J. D., Gulati, R., \& Shortell, S. M. 1997. Customization or conformity? An institutional and network perspective on the content and consequences of TQM adoption. Administrative Science Quarterly, 42(2): 366-394.

Yin, J., \& Zhang, Y., 2012. Institutional dynamics and corporate social responsibility (CSR) in an emerging country context: Evidence from China. Journal of Business Ethics, 111(2): 301316.

Zhao, M. 2012. CSR-based political legitimacy strategy: Managing the state by doing good in China and Russia. Journal of Business Ethics, 111(4): 439-460.

Zheng, Q., Luo, Y., \& Maksimov, V. 2015. Achieving legitimacy through corporate social responsibility: The case of emerging economy firms. Journal of World Business, 50(3): 389 403.

Zhu, Q., Cordeiro, J., \& Sarkis, J. 2012. International and domestic pressures and responses of Chinese firms to greening. Ecological Economics, 83: 144-153. 
Zhu, Q., Yin, H., Liu, J., \& Lai, K. H. 2014. How is employee perception of organizational efforts in corporate social responsibility related to their satisfaction and loyalty towards developing harmonious society in Chinese enterprises? Corporate Social Responsibility and Environmental Management, 21(1): 28-40.

Christopher Marquis (cmarquis@cornell.edu) is the Samuel G. Johnson Professor in Sustainable Global Enterprise at the Johnson Graduate School of Management, Cornell University. He received his $\mathrm{PhD}$ from the University of Michigan. He studies the environmental sustainability and shared value strategies of global corporations, with a particular emphasis on firms in China. Juelin Yin (yinjuelin@gmail.com) is an Associate Professor of Management at the International Business School Suzhou in Xi'an Jiaotong-Liverpool University. Her research focuses on the CSR strategies in emerging country contexts. She received her PhD from Nankai University, did her postdoctoral research in Harvard University, and was a visiting scholar in Ivey Business School, Western University. She has published over ten articles in journals such as Long Range Planning, Journal of Business Ethics and Business E Society.

Dongning Yang (dnyang@gsm.pku.edu.cn ) is an Associate Professor at the Guanghua School of Management, Peking University. He received his $\mathrm{PhD}$ in environmental science and engineering from Xiamen University. His current research focuses on the innovation and interaction of environmental sustainability issues, corporate social responsibility, and strategy management.

Manuscript received: April 30, 2015

Final version accepted: November 1, 2016 (number of revisions - 2)

Accepted by: Senior Editor Till Talaulicar 